\title{
SIKAP PROFESIONALISME DALAM PROFESI GURU
}

\author{
M. Taufik Ridhani \\ Email: 2010111210017@mhs.ulm.ac.id \\ Program Studi Pendidikan Sejarah Fakultas Keguruan dan Ilmu Pendidikan \\ Universitas Lambung Mangkurat \\ Banjarmasin
}

\begin{abstract}
Abstrak
Profesi merupakan suatu pekerjaan yang membutuhkan keahlian khusus. Tidak semua pekerjaan dapat disebut sebagai sebuah profesi namun semua profesi dapat disebut sebagai sebuah pekerjaan. Profesi merupakan suatu pekerjaan yang menuntut adanya sebuah kompetensi yang harus dimiliki. Guru merupakan salah satu pekerjaan yang dapat disebut sebagai sebuah profesi. Guru dapat disebut sebagai profesi karena guru telah memenuhi syarat-syarat yang telah ditetapkan agar dapat disebut profesi. Sebagai seorang guru wajib untuk memiliki sikap profesionalisme. Seorang guru juga harus memenuhi kompenen kompetensi yang telah ditetapkan agar dapat memajukan pendidikan bangsa Indonesia
\end{abstract}

\section{PENDAHULUAN}

Jika dilihat secara etimologi kata profesi diambil dari bahasa inggris yaitu profession yang berasal dari bahasa latin yaitu profesus yang memiliki arti mampu atau ahli dalam suatu bentuk pekerjaan. Profesi adalah bidang pekerjaan karena pada hakikatnya profesi adalah pekerjaan yang ditekuni seseorang (Nurhadi, 2017:2). Tidak semua pekerjaan dapat disebut sebagai sebuah profesi karena profesi merupakan suatu pekerjaan yang menuntut sebuah keahliaan yang harus dimiliki dalam melaksanakan pekerjaannya.

Guru merupakan suatu pekerjaan yang memiliki tugas untuk mendidik. Sebagai sebuah profesi guru harus memiliki sebuah keahlian dalam menjalankan pekerjaannya. guru merupakan suatu jabatan yang memerlukan keahlian khusus sebagai guru dan tidak dapat dilakukan oleh sembarang orang diluar pendidikan (Susanto, 2020: 17).

\section{PERAN GURU SEBAGAI SEBUAH PROFESI}

Guru dapat di golongkan sebagai sebuah profesi karena guru dapat memenuhi syaratsyarat yang harus dimiliki pekerjaan agar dapat disebut sebagai sebuah profesi. Menurut Susanto (2020: 14) secara umum syarat suatu pekerjaan untuk dapat digolongkan menjadi suatu profesi yaitu :

1. Memiliki spesialisasi ilmu

2. Memiliki kode etik dalam menjalankan profesi 
3. Memiliki organisasi profesi

4. Diakui masyarakat

5. Sebagai panggilan hidup

6. Dilengkapi kecakapan diagnostik

7. Mempunyai klien yang jelas

Jika dilihat dari pernyataan tersebut guru sudah memenuhi syarat syarat yang telah disebutkan diatas. Dan jika guru masih belum dapat memennuhi syarat syarat yang telah disebutkan maka masih belum pantas agar dapat disebut sebagai sebuah profesi.

Berdasarkan UU no. 14 tahun 2005 tentang guru dan dosen, guru memiliki tugas utama mendidik, mengajar, membimbing, mengarahkan, melatih, menilai, dan mengevaluasi peserta didik pada pendidikan anak usia dini jalur pendidikan formal, pendidikan dasar, dan pendidikan menengah.

Menurut Noor Jamaluddin (1978) sebagaimana dikutif Susanto (2020: 16) guru adalah pendidik, yaitu orang dewasa yang bertanggung jawab memberi bimbingan atau bantuan kepada anak didik dalam mengembangkan jasmani dan rohaninya agar mencapai kedewasaannya, mampu berdiri sendiri dapat melaksanakan tugasnya sebagai makhluk sosial dan individu yang sanggup berdiri sendiri.

\section{GURU INDONESIA DAN TANTANGAN PROFESIONALISME}

Guru merupakan profesi yang sangat berperan penting dalam memajukan pendidikan bangsa Indonesia. Oleh karena itu seorang guru wajib untuk memiliki sikap profesionalisme. Sikap profesionalisme sendiri merupakan suatu sikap untuk mencapai sebuah kesempurnaan dalam pekerjaan yang dilakukan. Tanpa adanya sikap profesionalisme maka kemajuan pendidikan bangsa Indonesia akan terganggu dan oleh sebab itu setiap guru diwajibkan untuk memiliki sikap profesionalisme

kompetensi guru merupakan seperangkat penguasaan pengetahuan dan kemampuan yang harus dimiliki guru agar dapat melaksanakan pekerjaannya secara benar dan bertanggung jawab (Baharun, 2017: 10-11). Menurut UU no 14 tahun 2005 tentang guru dan dosen, kompetensi guru meliputi kompetensi pedagogik, kompetensi kepribadian, kompetensi sosial, dan kompetensi profesional yang diperoleh melalui pendidikan profesi.

\section{SIMPULAN}

secara etimologi kata profesi diambil dari bahasa inggris yaitu profession yang berasal dari bahasa latin yaitu profesus yang memiliki arti mampu atau ahli dalam suatu bentuk pekerjaan. Profesi adalah bidang pekerjaan karena pada hakikatnya profesi adalah pekerjaan yang ditekuni seseorang (Nurhadi, 2017:2). Guru merupakan suatu pekerjaan yang memiliki tugas untuk mendidik. Sebagai sebuah profesi guru harus memiliki sebuah keahlian dalam menjalankan pekerjaannya. 
Menurut Susanto (2020: 14) secara umum syarat suatu pekerjaan untuk dapat digolongkan menjadi suatu profesi yaitu :

1. Memiliki spesialisasi ilmu

2. Memiliki kode etik dalam menjalankan profesi

3. Memiliki organisasi profesi

4. Diakui masyarakat

5. Sebagai panggilan hidup

6. Dilengkapi kecakapan diagnostik

7. Mempunyai klien yang jelas

Berdasarkan UU no. 14 tahun 2005 tentang guru dan dosen, guru memiliki tugas utama mendidik, mengajar, membimbing, mengarahkan, melatih, menilai, dan mengevaluasi peserta didik pada pendidikan anak usia dini jalur pendidikan formal, pendidikan dasar, dan pendidikan menengah.

Guru merupakan profesi yang sangat berperan penting dalam memajukan pendidikan bangsa Indonesia. Oleh karena itu seorang guru wajib untuk memiliki sikap profesionalisme. Menurut UU no 14 tahun 2005 tentang guru dan dosen, kompetensi guru meliputi kompetensi pedagogik, kompetensi kepribadian, kompetensi sosial, dan kompetensi profesional yang diperoleh melalui pendidikan profesi.

\section{REFERENSI}

Efendi, gI., Prawitasari, M., \& Susanto, H. (2021). Implementasi Penilaian Pembelajaran Pada Kurikulum 2013 Mata Pelajaran Sejarah. Prabayaksa: Journal of History Education, 1(1), 21-25.

Susanto, H. (2020). Profesi Keguruan. Banjarmasin: FKIP Universitas Lambung Mangkurat.

Susanto, uH., \& Akmal, H. (2018). Efektivitas Penggunaan Aplikasi Pembelajaran Berbasis Mobile Smartphone Sebagai Media Pengenalan Sejarah Lokal Masa Revolusi Fisik Di Kalimantan Selatan Pada Siswa Sekolah Menengah Atas. HISTORIA: Jurnal Program Studi Pendidikan Sejarah, 6(2), 197-206.

Susanto, H., Irmawati, I., Akmal, H., \& Abbas, E. W. (2021). Media Film Dokumenter Masuknya Islam Ke Nusantara dan Pengaruhnya Terhadap Keterampilan Berpikir Kritis Siswa. HISTORIA: Jurnal Program Studi Pendidikan Sejarah, 9(1).

Syaharuddrin, S., \& Susanto, H. (2019). Sejarah Pendidikan Indonesia (Era Pra Kolonialisme Nusantara sampai Reformasi). Banjarmasin: FKIP Universitas Lambung Mangkurat. 
Seri Publikasi Pembelajaran Vol 1 No 2(2021): Profesi Keguruan

Baharun, H. (2017). Peningkatan Kompetensi Guru Melalui Sistem Kepemimpinan Kepala Madrasah. At-Tajdid: Jurnal Ilmu Tarbiyah, 6(1), 1-26.

Nurhadi, A. (2017). Profesi Keguruan Menuju Pembentukan Guru Profesional. Kuningan: Goresan Pena. 